\section{SOME REMARKS ON THE CHRONOLOGY OF DENARII HOARDS FROM THE EASTERN CARPATHIAN BARBARICUM*}

\begin{abstract}
Over 100 denarii hoards dated in the $2^{\text {nd }}$ and $3^{\text {rd }}$ centuries $\mathrm{AD}$ were discovered in the Eastern Carpathian Barbaricum. Our paper aims to pinpoint a few aspects related to the chronology of these hoards, such as estimating the moment they arrived in the territory east of the Carpathians and for how long they were used in this particular area. In our research we analyse the available numismatic, archaeological and historical information. Thus, the composition and chronological structure of the coin hoards, the dating of their most recent monetary issues and the presence of barbarian imitations are taken into account. In some cases, the coins are associated in hoards with other categories of archaeological artifacts having their own dating, such as brooches, bracelets, silver and bronze vessels. Particularly important for establishing the chronology of coin hoards could be the ceramic pots and mugs in which they were housed and buried. Unfortunately, we have little information about the archaeological context of the hoards. Only in few cases they were found within the local settlements, or in their vicinity. Our attempt to date these hoards must also take into account the specific evolution of the relations between the Empire and barbarian populations located East of the Carpathians, as well as the political transformations that took place within this part of Barbaricum during the $2^{\text {nd }}-3^{\text {rd }}$ centuries AD.
\end{abstract}

Keywords: Moldavia, Eastern Barbaricum, coin hoards, $2^{\text {nd }}-3^{\text {rd }}$ centuries $A D$, barbarian imitations.

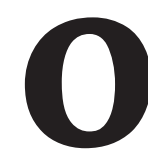

$\mathrm{n}$ the territory of Moldavia is attested one of the most important concentration of Roman imperial silver coins from the entire European Barbaricum. Up to the present, over 100 hoards were discovered in this small area, to the best of our knowledge, containing more than 25,000 denarii. This large database increases

\footnotetext{
"This study was funded through a grant offered by the Romanian National Authority for Scientific Research, CNCS - UEFISCDI, project number PN-III-P4-ID-PCE-2016-0669.
}

Lucian Munteanu

Institute of Archaeology Iași

lucanas2000@yahoo.com

\section{Ștefan Honcu}

Institute of Archaeology Iași

stefanhoncu@yahoo.com

DOI: $10.14795 /$ j.v7i1_SI.490

ISSN 2360 - 266X

ISSN-L 2360 - 266X 
regularly, by adding new recent discoveries, made especially with the help of metal detectors.

Different series of hoards can be identified $^{1}$, concluded in the same periods and having similar chronological structures. The first group of deposits, ending with coins of Hadrian, are small in size (8 hoards/over 150 pcs. $)^{2}$. They retain a substantial percentage of Republican issues, but the majority of coins are dated after Nero's reform. The most numerous are denarii of the Flavian emperors (especially Vespasian), and they are followed, at a short distance, by those of the emperors from the Antonine dynasty. The number of hoards with the latest issues of Antoninus Pius increases in Moldavia (14 hoards/over $1,600$ pcs. $)^{3}$. For the most part, they preserve their small dimensions and they are composed of two consistent cores, of almost equal size, of Flavian and Antonine denarii. The next series, dated in the time of Marcus Aurelius, contains the most part of discoveries (30 hoards/over 5,600 pcs. $)^{4}$. Generally, there are medium-sized deposits, which comprise between 100 and 200 denarii. Only some have in their composition Republican coins, especially Marcus Antonius' legionary series.

\footnotetext{
1 Only the hoards dated after the foundation of the province of Dacia, in AD 106, were took in consideration. 2 MIHAILESCU-BÎRLIBA 1980, 76-81; DEPEYROT/ MOISIL 2008a, 7-17; MUNTEANU 2017a, 925, 928, Fig. 1b; DYMOWSKI et alii 2019, nos. 263-264, 279, 286, 333 (to these should be added the hoards from Berzunți, Dămienești and Dângeni).

3 MIHAILESCU-BÎ́RLIBA 1980, 76-81; DEPEYROT/ MOISIL 2008a, 18-73; MUNTEANU 2017a, 925, 928, Fig. 1c; DYMOWSKI et alii 2019, nos. 105, 107, 111, 235, 244, 256, 262, 275, 280, 285, 299 (plus BereștiBistrița, Stolniceni-Prăjescu and Târgu Ocna).

4 MIHAILESCU-BÎRLIBA 1980, 81-87; DEPEYROT/ MOISIL 2008a, 74-138; MUNTEANU 2017a, 925, 928, Fig. 1d; MUNTEANU/MIHĂILESCU/DUMITROAIA 2017, 97-100, 123-125, 130-132; MUNTEANU/ MIHĂILESCU 2018, 219-221, 244-245, 257-258; DYMOWSKI et alii 2019, nos. 113, 234, 240, 248, 252, 261, 265, 268, 277, 281, 289, 295, 298, 302-303, 309, 311, 323, 326, 328-330 (plus Bistrița, Benești, Brehuiești, Olăreni, Tăcuta, Tansa and Tăvădărești). The most recent discovery from this series was made in 2016, at Hârtop (Neamț County) (167 denarii), with the help of metal detectors. The hoard is under study.
}

The amount of the Antonine emperors' coin issues exceeds that of the Flavian ones.

The hoards concluded in the time of Commodus continue to be in a great amount (21 hoards/over 7,800 pcs.) $)^{5}$. In their composition, the core of the coins belonging to the Antonine emperors develops considerably, reaching over $80 \%$ of all discoveries. This percentage is relatively evenly divided by the emperors of this dynasty, beginning with Trajan. The largest number of denarii may be found in the deposits with terminal coins of Septimius Severus (22 hoards/over $10,800$ pcs. $)^{6}$. Some of them are quite large, exceeding 1,000 coins. Generally, they share a quite similar chronological structure to those from Commodus, therefore, when a partial discovery that could be assigned to this period is recovered, it is very difficult to attribute it accurately. In most of the deposits from this series, the latest recorded issue is dated before the significant reduction in the silver content suffered by denarii (AD 194) ${ }^{7}$, but, in a few cases, the hoards contain issues struck after this event as well.

Furthermore, only two horizons of hoards concluded after the reign of Septimius Severus are represented in the Eastern Carpathian area. Unfortunately, there are missing precise information on the deposits from the time of Caracalla (2 hoards/over 160 pcs. $)^{8}$. But those from the following period (Elagabalus - Severus Alexander) (4 hoards/

\footnotetext{
5 MIHAILESCU-BÎRLIBA 1980, 87-93, 97; DEPEYROT/ MOISIL 2008a, 139-193; MUNTEANU 2017a, 925, 928, Fig. 1e; DYMOWSKI et alii 2019, nos. 109, 238-239, 255 , 257, 267, 269, 304-305, 308, 310, 315, 320, 322, 325 327, 331, 334, 337 (plus Galați-Barboși and Schineni). 6 MIHAILESCU-BÎRLIBA 1980, 94-100; DEPEYROT/ MOISIL 2008a, 194-283; MUNTEANU 2017a, 925, 928, Fig. 1f; DYMOWSKI et alii 2019, nos. 106, 108, 110, 112 233, 236-237, 242, 260, 266, 270, 276, 284, 290, 292 294, 301, 312-313, 317. In 2015, another hoard (200 pcs.) was discovered inside the site of Ruginoasa (Neamt County), also with the help of metal detectors (HONCU/ GAFINCU 2018, 219). The hoard is under study.

7 BUTCHER/PONTING 2012, 77.

8 MIHAILESCU-BÎRLIBA 1980, 100-103; MUNTEANU 2017a, 925, 928, Fig. 1f; DYMOWSKI et alii 2019, nos. 282, 335.
} 
over 1,200 pcs.) $)^{9}$ are well studied, therefore their chronological structure is known. They contain a small group of Flavian denarii, a consistent core of coins from the time of the Antonines, whose peak reaches the time of Antoninus Pius, and very few recent issues. Thereafter, only a few denarii still appear in the composition of two antoninianii hoards, concluded in the time of Trebonianus Gallus ${ }^{10}$ and Aemilian ${ }^{11}$.

In general, the various issues related to denarii hoards discovered on the territory of Moldavia - the chronology, ways of penetration and functions - have been thoroughly studied, especially in the works of V. MihailescuBîrliba ${ }^{12}$. The results he has achieved are well known, so we do not aim to resume the whole discussion. Our intention is to reconsider some aspects which refer to the chronology of these hoards. More precisely, we will try to presume when the imperial denarii arrived in the territory East of the Carpathians and for how long they were used in this particular area.

There are numerous hypotheses seeking to date the influx of denarii into different parts of the European Barbaricum, situated close to the limes or far from the Empire's borders ${ }^{13}$. In the case of Moldavia, it is assumed that silver coins entered the region only after the monetary reform of Septimius Severus, till the reign of Elagabalus or maybe later, up to the time of Trajan Decius/Gallienus. As an effect of this debasement, the pre-Severan denarii of good quality were taken out of circulation and amassed inside the Empire, according to Gresham's law. From this existing monetary

\footnotetext{
9 MIHAILESCU-BÎRLIBA 1980, 103-106; DEPEYROT/ MOISIL 2008a, 284-352; MUNTEANU 2017a, 925, 928, Fig. 1g-h; MUNTEANU/POPUȘOI 2014, 12-14, 28, 34; DYMOWSKI et alii 2019, nos. 241, 249, 283, 296.

10 DEPEYROT/MOISIL 2008b, 171-172; MUNTEANU 2017a, 925, 928, Fig. 1j.

11 DEPEYROT/MOISIL 2008b, 173; MUNTEANU 2017a, 925, 928, Fig. 1j; DYMOWSKI et alii 2019, no. 297.

12 See, in particular, MIHAILESCU-BÎRLIBA 1980, and more recently, MIHAILESCU-BÎRLIBA 2012.

13 A summary of these opinions can be found at: BURSCHE 1993; LUCCHELLI 1998, 130-163; DYMOWSKI/MYZGIN 2014, 42-44, 48-56; VOß/ WIGG-WOLF 2017, 114-119.
}

fund ("trésor unique de l'Empire Romain"), they were sent outside the limes ${ }^{14}$. The research of the hoards, both in terms of chronological structure and composition, and the analysis of historical events in the barbarian territory East of the Carpathians could lead to different conclusions. The chronological structures of the denarii hoards discovered in Moldavia, concluded in various times, is almost similar to the ones of the majority of the contemporary deposits discovered in the neighbouring Roman provinces (Dacia and Moesia Inferior) ${ }^{15}$. Both types of hoards were formed within the Roman borders and reflect the monetary circulation in the Empire at a certain time. The removal of the denarii from the coinage pool was made gradually, in various periods (not all of a sudden), generating hoards with distinct chronological structures. They were carried over the limes as already collected amounts, set up in different times.

In most of the cases directly observed by ourselves the latest coins from the Moldavian hoards, especially those from the earlier series (ended in the time of Hadrian - Marcus Aurelius) were preserved in very good condition. The absence of visible traces of wear on their surface would suggest that these denarii circulated only for a short while inside the Empire, being withdrawn by the authorities at a time close to their issuance. In this kind of situations, it is possible that the most recent coins from a hoard discovered in the East Carpathian Barbaricum to virtually indicate the moment when it reached beyond the limes ${ }^{16}$.

14 MIHAILESCU-BÎRLIBA 1980， 109， 201-202; MIHAILESCU-BÎRLIBA 1981; MIHAILESCU-BÎRLIBA 1983-1985; MIHAILESCU-BÎRLIBA 1994, 69-70; MIHAILESCU-BÎRLIBA 2012, 508-509.

15 For the hoards from Dacia and Moesia Inferior see: DEPEYROT/MOISIL 2008a; GĂZDAC 2010, 67-77, 126-137 and Catalogues (Hoards from Dacia; Hoards from Moesia Inferior); PETAC 2011, 224-262. An exhaustive comparative analysis of the denarii hoards from Moldavia and the Empire was conducted by V. Mihailescu-Bîrliba (MIHAILESCU-BÎRLIBA 1980 75-176; MIHAILESCU-BÎRLIBA 1981; MIHAILESCUBÎRLIBA 1983-1985).

16 MUNTEANU/MIHĂILESCU/DUMITROAIA 2017, 95, 100; MUNTEANU/MIHĂILESCU 2018, 215, 222. 
In the composition of theimperial hoards from Moldavia sometimes occur particular monetary issues, such as the provincial coinage and the plated denarii, which may reveal useful chronological indications. So far, we have knowledge of 20 civic and provincial silver coins that were hoarded together with the denarii in this area. They are all dated during Vespasian - Hadrian and were struck in various mints from the Oriental part of the Empire (Lycia - 11 pcs., Caesarea Cappadociae - 5 pcs., Amisos Ponti - 3 pcs. $)^{17}$ and even from outside (1 pc. - Parthian Empire) ${ }^{18}$. Characterised by a satisfactory weight and a high title, these drachmas were accepted in the monetary circulation inside the Empire along with denarii, and probably equated with them on a certain tariff ${ }^{19}$. Similar provincial issues turned up in the composition of the hoards from the province of Dacia, the nearest Roman territory and a potential source for the Roman coins from Moldavia. It may be noted that all these hoards are ended, at the latest, during Commodus ${ }^{20}$.

Denarii subaerati are frequently encountered in the composition of the hoards discovered in the Eastern Carpathian territory. We managed to record at least 32 such issues, found in 14 hoards $^{21}$. They were made by striking and, exceptionally, by casting and most of them belong to the Antonine emperors $(27 \text { pcs. })^{22}$. The origin of these particular coins

17 MUNTEANU/POPUȘOI 2014, 10; MUNTEANU/ MIHĂILESCU/DUMITROAIA 2017, 96, 113-114, nos. 59-60; MARINESCU-BÎLCU/CHIȚESCU/MIHAILESCU-BÎRLIBA 1989, 49, no. 34; DIMA/VASILE 2003, 95, no. 36; DUMITROAIA 2013-2014, 458, no. 3; BUTNARIU 2016, 46, no. 76.

${ }_{18}$ DIMA/VASILE 2003, 95, no. 37.

${ }^{19}$ MARINESCU-BÎLCU/CHIȚESCU/MIHAILESCU-BÎRLIBA 1989, 45.

20 GĂZDAC 2010, 159 and Catalogues (Hoards from Dacia).

${ }^{21}$ MUNTEANU/POPUȘOI 2014, 5-6, 18, no. 21, 24; 19 , nos. $25 ; 22$, nos. $44-45$. In reality, it is possible that the number of plated coins in the composition of the Moldavian hoards be much higher, these being difficult to detect with the naked eye, in the absence of any physical and chemical analyses.

22 MUNTEANU/POPUȘOI 2014, 3-6; MUNTEANU 2017a, 925. must be sought in the two Roman provinces located in the vicinity: Moesia Inferior and Dacia. In the province South of the Danube, the sporadic reporting of counterfeit denarii is probably due to the inadequate publication of monetary discoveries ${ }^{23}$. By comparison, a different situation is attested in Dacia. Massive amounts of silver plated coins, manufactured, especially by striking, were found isolated, both in the civilian settlements and military sites of the province. They occur in all periods, but the greatest part bears the effigies of the Severan emperors ${ }^{24}$. The number of counterfeit coins in the composition of Dacian hoards is smaller and the majority are Severan denarii ${ }^{25}$. The emergence of a deposit of cast coins at Apulum (VI) seems to be an exceptional case $^{26}$. All the denarii subaerati, made by striking, from the Moldavian hoards, are dated prior to the reign of Septimius Severus. We can assume that most of these deposits were constituted in the Roman world and reached this part of Barbaricum before the phenomenon of copying escalated in the Empire $^{27}$. In a later period, when the silvered copies became widely available, they were included in the composition of the hoards, together with the genuine coins. It is the case of the deposit from Iezer (Vaslui County), concluded in the time of Severus Alexander, which contains three cast forgeries in $\mathrm{Cu}^{-}$ $\mathrm{Sn}-\mathrm{Pb}$ alloys ${ }^{28}$, very similar to those from the hoard of Apulum $\mathrm{VI}^{29}$.

At last, the chronology of the main

${ }^{23}$ GATTORNO 1940; DIMA/ELEFTERESCU 2009, 2025, 142-147; GÄZDAC 2010, 177.

24 GĂZDAC 2009; GĂZDAC 2010, 150-151, 177; MUNTEANU 2017b, 87-92, 135-136, 156; MUNTEANU/HONCU 2019, 174-181.

25 GĂZDAC 2010, 136 and Catalogues (Hoards from Dacia).

${ }^{26}$ GĂZDAC/OARGĂ/ALFÖLDY-GĂZDAC 2015.

${ }^{27}$ At the beginning of the $3^{\text {rd }}$ century, the copying of main bronze and silver denominations would have been widely done, especially in the Danubian and Rhenanian provinces (see GĂZDAC 2010, 177-178; MUNTEANU/ HONCU 2019, 179-180, with the bibliography).

${ }_{28}$ MUNTEANU/POPUȘOI 2014, 3-4; 18-19, nos. 21, $24-25$.

29 GĂZDAC/OARGĂ/ALFÖLDY-GĂZDAC 2015, 8-15, 38-45, Tab. 2. 
political and military events that would explain the presence of Roman silver in the territory East of the Carpathians should be considered. Immediately after the establishment of the Romans North and South of the Danube, barbarians from this area were attracted by the territories of the Empire. At the beginning of the reign of Antoninus Pius, in AD 143 - 144, the "Dacians" from Moldavia attacked both Moesiae, moving by boats along the Danube ${ }^{30}$. Only a few years later (AD 155 - 157/158), probably the same tribes were raiding in the Eastern part of Dacia Superior ${ }^{31}$. About these barbarians one can only assume that they originate from central and Northern Moldavia ${ }^{32}$. We believe that their possible identification with the Costoboci should be considered. This tribe was manifested quite active in relations with the Empire during this period. Recent research has shown that "Lipița" archaeological culture cannot be ascribed to them with certainty, so it is impossible to specify where their home territory was located ${ }^{33}$. During Marcomannic wars, the Costoboci are listed by Historia Augusta among the enemies of the Empire (M. Ant. Phil., 22, 1). In AD 170 or 172 they ran a violent expedition to the South of the Danube, crossing the provinces of Moesia Inferior, Thracia, Macedonia and reaching the centre of Greece, where they were defeated (Pausanias, $\mathrm{X}, 34,5)^{34}$. At the same time, an inscription in Rome mentions Pieporus, rex Coisstobocensis (CIL, VI, 1801), a client king of the Empire and probably an important barbarian ruler.

Carpi were probably the most important tribe living in this barbarian territory. Their archaeological culture, named "Poienești - Vârteșcoiu", developed especially in the sub-Carpathian area and central Moldavia, reaching its peak in the second half of the $2^{\text {nd }}$ century and the first part of the $3^{\text {rd }}$ century ${ }^{35}$.

\footnotetext{
30 BENEA 2010, 157-159; BENEA 2013, 62-63.

31 BENEA 2010, 162-168; BENEA 2013, 64-65.

32 BENEA 2010, 155, 158, 163; BENEA 2013, 63, 65.

33 POPA 2015, 18-24; POPA 2016.

34 POPA 2015, 21-22; POPA 2016, 139-141.

35 For the "Poienești-Vârteșcoiu" archaeological culture/
}

This tribe became noticeable only after the Costoboci's defeat. During Caracalla's reign, the Carpi may have raided the territory of Tyras $^{36}$. In $\mathrm{AD} 238$, they attacked the province of Moesia Inferior (SHA, Max. et Balb., 16, 3) and asked the governor, Tullius Menophilus, to give them subsidies, believing themselves "more worthy than the Goths" (Petrus Patricius, 8). An important event for the Empire was represented by the war of Philippus Arabs with the Carpi (c. AD 245 247). The emperor repelled the barbarians who had attacked Dacia and besieged them in a fortress ( $\phi$ poúpiov) (Zosimos, I, 20) ${ }^{37}$. Subsequently, the Carpi, alone or together with the Goths, made frequent raids in the Roman territories; at the end of century, this tribe was moved en masse South of the Danube $^{38}$.

Following this brief analysis, it is more likely to consider that the imperial denarii hoards have reached this part of Barbaricum gradually, in different periods. They arrived here already formed and their composition and chronological structure reflect the coinage pool from the Empire at that particular moment when their constitution took place. Their flow beyond the eastern limes (as robberies, military payments or stipendia) $)^{39}$ probably started during Antoninus Pius (or even earlier), when the first attacks of the barbarians from Moldavia (Costoboci ?) occurred. The influx of silver coins increased during the Marcomanic wars, in which the Costoboci considerably engaged. In connection with them, may be interpreted the majority of the hoards concluded in the time of Marcus Aurelius and, perhaps, some of those in the later period (Commodus). From the end of the $2^{\text {nd }}$ century until the middle of the $3^{\text {rd }}$, the warrior tribe of Carpi represented

group (identified with the "Carpic" culture - BICHIR 1973, 158-159) see, more recently, POPA 2015, 30-35.

36 PETOLESCU 1988; PETOLESCU 2010, 300-301.

37 TUDOR 1976; PETOLESCU 2010, 302-303; this fortress (castellum Carporum) is also mentioned on an inscription from Intercisa (ÁE 1965, 223).

38 DIACONU 1986; PETOLESCU 2010, 303-305.

39 MIHAILESCU-BÎRLIBA 2012, 509; MUNTEANU 2017a, 926. 
a significant threat for the Empire. They asked for and received stipendia, being probably more important than the Goths at that time. Most of the sizeable deposits with terminal coins of Septimius Severus and those of a later date (Elagabalus - Severus Alexander) might be attributed to them. In all likelihood denarii continued to arrive in the Eastern Carpathian territory even after Septimius Severus' changes in his politics towards barbarians ${ }^{40}$. During this period, the silver received from the Romans was perhaps concentrated in the hands of some local leaders ${ }^{41}$, subsequently being redistributed, in a sort of "secondary exchange".

Another issue related to the chronology of the denarii hoards discovered in Moldavia refers to the length of time they have been used in this barbarian territory. Estimating the moment when these deposits were buried, in an environment where they were no longer used as money, but invested with other functions, is very difficult to achieve. Some relative chronological support we might obtain from the analysis of objects that were added to the coins coming from the Empire (like barbarian imitations and various precious metal artefacts), the study of the ceramic pots and mugs in which they were housed, and the archaeological contexts in which they were dug.

The barbarian imitations of imperial denarii occurred in the Moldavian hoards, usually one-two pieces in each discovery. Up to the present, we have knowledge of 42 such particular issues. Half of them were published, only in a few cases being illustrated ${ }^{42}$. Other 21 counterfeit coins are still unpublished and they belong to the hoard of Muncelu de Sus (Iași County) ${ }^{43}$. We consider it necessary to

\footnotetext{
40 VOß/WIGG-WOLF 2017, 117-119.

${ }_{41}$ Presumptive barbarian power centres were archaeologically identified in Moldavia (OPREANU 1994, 213215).

42 MUNTEANU/POPUSSOI 2014, 8-9; MUNTEANU/ MIHĂILESCU 2018, 217, 235, no. 84.

43 This exceptional hoard was recovered in several batches: I. year 1963; 371 coins (unpublished); II. year 1972; 7 silver vessels; III. year 1974; 819 coins, a fragment from a silver vessel and a fibula; IV. year 1976; 669 coins and a bronze vessel (a summary for these four
}

briefly refer to these coins, because among them are the only barbarian imitations attested so far in Moldavia, which were struck with the same dies. In this hoard, four groups of imitative coins were identified, sharing identical dies for the obverse and/or the reverse. It is remarkable that one of these groups is die-linked to an imitation known from the hoard of Târpești (Neamț County) ${ }^{44}$. In the composition of the same discovery, from Muncelu de Sus, there is also a silver coin that copies a rare bronze issue of Plautilla, minted at Nicaea Bithyniae.

The imitative issues are found in 14 hoards from Moldavia, concluded at different times. A significant concentration of this coinage (32 pcs.) is noticeable within the deposits ended with genuine denarii of Marcus Aurelius. The most commonly used prototypes are the coins of the Antonine emperors, especially of Antoninus Pius (9 pcs.), Marcus Aurelius (10 pcs.) and Faustina II (6 pcs.). Some of these counterfeits are hybrids. The weights of imitative coins vary a lot; most are below 3 grams, but there is also a small group of pieces that exceed 5 grams. Depending on the degree of barbarisation, they belong to all the three known groups, but, in utmost situations, the imperial portrait can be fairly easy to distinguish. The legends contain both Latin and Greek characters and sometimes graphic symbols trying to imitate the letters. For the most part they are combined $^{45}$. To our knowledge there are no direct die-links between the imitations found in Moldavia and similar coins from other parts of Barbaricum ${ }^{46}$. Only in very few cases

batches see at: MITREA/MIHAILESCU-BÎRLIBA 2001, 66-67, 70); V. 9 coins (MOISIL 2010); VI. 54 coins; private collection (unpublished). The 21 imitative coins belong to the batches nos. III and VI. Unfortunately, we do not have yet the permission to use the pictures of these coins.

44 MARINESCU-BÎLCU/CHIȚESCU/MIHAILESCU-BÎRLIBA 1989, 51, no. 135.

45 MUNTEANU 2017a, 925; MUNTEANU/POPUȘOI 2014, 8-9; MUNTEANU/MIHĂILESCU 2018, 217.

46 STRIBRNY 2003; LIND 2007; LIND 2018; SERGEEV 2012, 73-75, 89-140; CZERNEK 2013; HORSNÆS 2013, 55-56; ANOHIN 2015; DYMOWSKI 2017; 
the same Roman prototypes have been used, although imitated in a different manner ${ }^{47}$.

The origin of barbarian imitations found in Moldavia was searched especially in the Greek cities from the Northern or Southern coast of the Black Sea ${ }^{48}$. The hypothesis of manufacturing these coins even in the territory East of the Carpathians, in the period before the arrival of the Goths, seems more plausible ${ }^{49}$. The occurrence of imitative issues struck with the same pairs of dies, and the existence of die-links between imitations from different hoards might suggest the operation of local workshops, as in other parts of Barbaricum (Pannonian Basin, Denmark, Poland or Ukraine). It is difficult to presume when exactly this coinage was produced, but it may most likely be attributed to the local population, of Geto-Dacian origin. The counterfeit denarii were added to the hoards afterwards, while they were already outside the limes. Their presence indicates that some deposits continued to survive for a while in the barbarian territory East of the Carpathians. It is the case of the hoard from Muncelu de Sus, which concludes with genuine denarii of Marcus Aurelius, but contains an imitation of a civic coin of Plautilla as well.

There are only few situations in Moldavia when the coins are associated in hoards with other categories of archaeological artefacts such as brooches, bracelets, silver and bronze vessels. Most of them are of Roman origin and have their own dating. Some of these are broken from ancient times, so we believe that they were added to the coins later on, even in the barbarian territory.

The oldest such hoard, found in Dersca (Botoșani County), contains a silver bracelet characterised by a lower quality metal core ${ }^{50}$.

\footnotetext{
DYMOWSKI 2018; SIDAROVICH 2017, 131-141.

47 MUNTEANU/MIHĂILESCU 2018, 216-217.

48 MIHAILESCU-BÎRLIBA/MITREA 1975, 18; MIHAILESCU-BÎRLIBA 1980, 220; MIHAILESCU-BÎRLIBA 1991, 60. MITREA/MIHAILESCU-BÎRLIBA 20002001, 201.

49 MUNTEANU 2017a, 925; MUNTEANU/POPUȘOI 2014, 10; MUNTEANU/MIHĂILESCU 2018, 218.

50 SANIE/ȘADURSCHI 1976, 87-88, Fig. 3; BUTNARIU 2010, 18; OANȚĂ-MARGHITU 2013, 530-531, no.
}

Such bracelets are broadly dated between the $1^{\text {st }}$ century $\mathrm{BC}$ and the $1^{\text {st }}$ century AD. The find from Dersca pertains rather to the upper limit of that time frame ${ }^{51}$, as the latest coins in this hoard are denarii of Hadrian ${ }^{52}$. The most important discovery in this category is the hoard complex of Muncelu de Sus. Here, in a confined area of several tens of square meters, in the 1960s and 1970s, three coin hoards were uncovered (over 1,900 pcs.) containing various artifacts (a fibula a fragment from a silver vessel, which were lost, and perhaps two bronze vessels $)^{53}$, as well as a deposit of seven silver vessels ${ }^{54}$. Preserved in pieces, the bronze vessels are represented by jugs with a human foot decorated handle (of type Tassinari II) and fitted within a fairly large chronology. They were produced at the end of the $1^{\text {st }}$ century $\mathrm{AD}$ and the beginning of the next one, but found in discoveries dated during the first three centuries $\mathrm{AD}^{55}$. The silver deposit contained seven vessels, but only six were recovered: four cups (two cylindrical and two hemispherical) forming a wine vessel set, an Eggers type casserole and a fragment from an unidentified vessel. The treasure was dated between the $2^{\text {nd }}$ century and the beginning of the $3^{\text {rd }}$ century $\mathrm{AD}$, having compelling analogies with the discoveries of Manching and Lauriacum ${ }^{56}$.

Another coin hoard of considerable size (735 pcs.), found at Oboroceni (Iași County), contains a broken "T-shaped" type fibula, made of inferior quality silver. Such brooches appear frequently in Roman forts on the Rhine and Danube limes, and date back to

143.1.

51 RUSTOIU 1996, 47, Fig. 1.7.

52 SANIE/ȘADURSCHI 1976, 85; BUTNARIU 2010, 18 (AD 119-122).

53 SANIE/SANIE/COJOCARU 1980; BUTNARIU 2001, 10-20; MITREA/MIHAILESCU-BÎRLIBA 2001, 66-67.

54 MIHAILESCU-BÎRLIBA/MITREA 1978; OANȚĂMARGHITU 2013, 521-524; POPA 2015, 120-127.

55 SANIE/SANIE/COJOCARU 1980, 249-250, Pl. I; SANIE 1981, 178-179, Pl. 52/1, 5, 8; BUTNARIU 2001, 20; POPA 2015, 135, Ab. 102.1; SPÂNU/DIMA/ FRÂNCULEASA 2016, 243-245.

56 MIHAILESCU-BÎRLIBA/MITREA 1978; OANȚĂMARGHITU 2013, 521-524; POPA 2015, 120-127. 
the end of the $2^{\text {nd }}$ century and the first half of the $3^{\text {rd }} \mathrm{AD}^{57}$. In the same category could be included also one of the biggest coin hoards in the entire European Barbaricum, the one discovered within the settlement of Măgura (Bacău County) (over 3,099 pcs.) ${ }^{58}$. A fragment of gold thread was identified among the coins, which first led to the assumption that it might come from the section of a fabric ${ }^{59}$. After studying the minute item $(21 \mathrm{~mm})$, we have noticed that there were traces of processing, by beating, on its surface, which would argue for its provenance in a piece of jewellery ${ }^{60}$.

Most of the denarii hoards from Moldavia were housed and buried in ceramic pots and mugs. We have information about 44 such containers, but only 22 of them have been preserved, being available for study ${ }^{61}$. As a result, we have managed to identify two categories of pots that date back to different times. The first class is represented by small pots that were hand-made ${ }^{62}$. They date back between the $2^{\text {nd }}$ century $\mathrm{BC}$ and the $2^{\text {nd }}$ century $\mathrm{AD}$. The end dates of the hoards they contain do not exceed the limits of the $2^{\text {nd }}$ century AD. Similar vessels were specifically discovered in the sites of the classical "Geto-Dacian" culture, dated before the Roman conquest ${ }^{63}$. The second category of ceramic containers is represented by mugs of different sizes that are worked on the pottery wheel. Chronologically, they belong to the $2^{\text {nd }}-3^{\text {rd }}$ centuries $\mathrm{AD}$ and share numerous analogies among the discoveries made in the settlements and necropolises belonging to the "Poienești-Vârteşcoiu" archaeological culture ${ }^{64}$. We believe that the

\footnotetext{
57 MITREA/ZAHARIA 1967 (the latest coin is dated in AD 195); HONCU/MUNTEANU 2018.

58 MIHAILESCU-BÎRLIBA/MITREA 1977 (t.p.q. AD 194-195); MOISIL 2012, 302-303.

${ }^{59}$ MIHAILESCU-BÎRLIBA/MITREA 1977, 16, 20.

${ }^{60}$ HONCU/MUNTEANU 2018, 161 (Inv. no. 17382).

61 IGNAT 1986-1987; MIHAILESCU-BÎRLIBA 1998, 472-479, nos. 1-18; 480-482, Taf. I-III; BUTNARIU 2001, 110; DUMITROAIA 2013-2014, 472, Pl. VI/2; MUNTEANU/MIHĂILESCU 2018, 218-219, 248, Pl. III/2; MUNTEANU/MIHĂILESCU/DUMITROAIA 2017, 101-102, 128, Fig. 4.

${ }^{62}$ MIHAILESCU-BÎRLIBA 1998, 469-470.

${ }^{63}$ URSACHI 1995, type I, pl. 52/11 and 53/2, 3.

${ }^{64}$ BICHIR 1973, 63-88; IONIȚĂ/URSACHI 1988, 69-
}

mugs in this category can be divided into two different groups, based on their size and particular morphological traits (especially the shape of the lip) ${ }^{65}$. It is interesting to note that the two distinct groups of mugs were storing hoards from successive periods: those ending with coins of Antoninus Pius - Marcus Aurelius and Commodus - Septimius Severus, respectively ${ }^{6}$.

What it is certain is that none of the ceramic vessels that have housed denarii deposits on the Moldavian territory exceeds the chronological limit of the first half of the $3^{\text {rd }}$ century AD. They belong exclusively to the native pottery and have relevant analogies in the discoveries undertaken in the classical "Geto-Dacian" culture settlements and later on, in the "Poienești-Vârteşcoiu" sites ${ }^{67}$.

The archaeological contexts in which the imperial coin hoards were found could provide important chronological information. Only for about one third of the denarii deposits from this part of Barbaricum the conditions of discovery are known. Each time they relate to the local settlements of "PoieneştiVârteşcoiu" type. Several specific situations within the relation between settlements and hoards can be identified. Extremely rare are the cases in which the deposits were found during excavations, in the archaeological cultural layer of the settlement. Most often the coins were found first, accidentally, and only after, specialized investigations were carried out in the very same place, thus allowing the identification of the sites. In happier cases, rescue excavations have been performed to allow a rigorous documentation of the anthropogenic activities (dwellings, pits, etc.) or the archaeological levels in these points. In most cases, the existence of these alleged sites was recorded on the basis of simple reconnaissance surveys, which resulted in

\footnotetext{
71, MIHAILESCU-BÎRLIBA 1998, 470. MUNTEANU/ MIHĂILESCU/DUMITROAIA 2017, 101-102; MUNTEANU/MIHĂILESCU 2018, 218-219.

65 BICHIR 1973, 81-85.

66 MIHAILESCU-BÎRLIBA 1998, 471-472.

67 MIHAILESCU-BÎRLIBA 1998, 472; MIHAILESCUBÎRLIBA 2012, 509.
} 
the collection of various artefacts (especially ceramic materials). Finally, a fairly frequent situation is the appearance of the coin hoards in the vicinity of sites already reported in the literature (on average, at distance of $1-2 \mathrm{~km})^{68}$. Interesting observations may also come from tracking the geographic distribution of the imperial hoards found in Moldavia. One can notice their concentration in the subCarpathian area and in the middle of the province, along the valley of Siret river ${ }^{69}$. This territory corresponds broadly to the spread of the "Poieneşti-Vârteşcoiu" archaeological culture, attributed to the Geto-Dacian population of $\mathrm{Carpi}^{70}$. For a later period, there is no documented situation in which the coin deposits might be related to the vestiges of the "Sântana de Mureş-Chernyakhov" culture ${ }^{71}$.

In all the situations we have analyzed, denarii hoards discovered in the Eastern Carpathian Barbaricum can only be linked to local populations, of Geto-Dacian origin (Costoboci, Carpi), and their archaeological remains. These tribes received or took by themselves, used and buried impressive quantities of Roman silver in the form of coins, which were associated with various precious metal artefacts in a later period.

Proofreading: Natalia Midvchi Kriaf

\section{REFERENCES}

ANOHIN 2015

Anohin, O. V., Fals' šivomonetčestvo u varvarskih plemën na territorii sovremennoj Ukrainy i Moldovy. Katalog

\footnotetext{
68 A detailed investigation of the contexts in which the hoards concluded in the time of Marcus Aurelius were discovered, see at: MUNTEANU/MIHĂILESCU 2018, 222. Broadly, this pattern applies to all the series of denarii deposits found in Moldavia.

69 MIHAILESCU-BÎRLIBA 1980, 119, 131; MIHAILESCU-BÎRLIBA 1994, 70; MUNTEANU 2017a, Fig. 1.

70 POPA 2015, Taf. 3; unfortunately, the territory inhabited by Costoboci cannot be identified with certainty (vide infra).

${ }^{71}$ On the chronology of this culture, see, more recently, MAGOMEDOV 2001, 139-147, 287-290, Figs. 88-91 (it is assumed that the western territorial limit of this culture exceeds the Prut river only in phase C2 and at the beginning of phase C3 - AD c. 270-330).
}

varvarskih podražanij (Dnipropetrovs'k: Seredniak T.K.).

\section{BENEA 2010}

Benea, D., Despre războaiele cu dacii din timpul lui Antoninus Pius (anii 144/147, 155-157). In: Rusu-Bolindeţ, V./Sălăgean, T./Varga, R. (eds.), Studia Arcaeologica et Historica in Honorem Magistri Dorin Alicu (Cluj-Napoca: Argonaut), 154-180.

\section{BENEA 2013}

Benea, D., Istoria Banatului în Antichitate (Timișoara: Excelsior art).

\section{BICHIR 1973}

Bichir, Gh., Cultura carpică (București: Academia R.S.R.).

BURSCHE 1993

Bursche, A., Pourquoi les denarii frappés après 194 etaient absent dans le Barbaricum?. In: Moucharte, G./ Hackens, T. (dir.), Actes du XI ${ }^{\mathrm{e}}$ Congrès international de numismatique: organisé à l'occasion du 150e anniversaire de la Société royale de numismatique de Belgique: Bruxelles, 8-13 septembre 1991. II. Monnaies celtiques et romaines (Louvain-la-Neuve: Cultura), 297-303.

BURSCHE 2011

Bursche, A., Ilerup Ådal. 14. Die Münzen (Aarhus: University Press).

\section{BUTCHER/PONTING 2012}

Butcher, K./Ponting, M., The beginning of the end? The denarius in the second century, The Numismatic Chronicle 172, 64-83.

\section{BUTNARIU 2001}

Butnariu, V. M. (coord.), Monnaies et parures du Musée d'Histoire de la Moldavie de Iași (Iași: Vasiliana '98).

BUTNARIU 2010

Butnariu, V. M. (éd.), Monnaies et parures du Musée Départemental de Botoşani (Gura Humorului: Terra Design).

\section{BUTNARIU 2016}

Butnariu, V. M. (éd.), Découvertes monétaires du Complexe Muséal „Iulian Antonescu" Bacău (Onești: Magic Print). 


\section{CZERNEK 2013}

Czernek, D., A Barbarous Imitation of a Roman Denarius from Skowronno Dolne, gmina Pińczów, Świętokrzyskie Voivodeship, Notae Numismaticae Zapiski Numizmatyczne 8, 143-154.

\section{DEPEYROT/MOISIL 2008A}

Depeyrot, G./Moisil, D., Les trésors de deniers de Trajan à Balbin en Roumanie (Wetteren: Moneta 73).

DEPEYROT, MOISIL, 2008B

Depeyrot, G./Moisil, D., Les trésors de deniers et d'antoniniens de Gordien III à Aurélien en Roumanie (Wetteren: Moneta 78).

\section{DIACONU 1986}

Diaconu, P., „Satul Carpilor” sau „un sat al carpilor", Cultură şi Civilizaţie la Dunărea de Jos 2, 205-207.

\section{DIMA/ELEFTERESCU 2009}

Dima, M./Elefterescu, D., Monnaies de Durostorum - Ostrov (4e siècle av.J.-C. 6 e siècle ap. J.-C.) (Wetteren: Moneta 88). DIMA/VASILE 2003

Dima, M./Vasile M., Tezaurul de la Puiești, jud. Vaslui. In: Nicolae, E. (red. resp.), Simpozion de numismatică dedicat împlinirii a 125 de ani de la proclamarea independenței României. Chișinău, 24-26 septembrie 2002. Comunicări, studii și note (București: Enciclopedică), 91-96.

DUMITROAIA 2013-2014

Dumitroaia, Gh., Semnalări de piese arheologice, numismatice și cu semnificație istorică din colecții particulare confiscate și descoperiri făcute cu ajutorul detectorului de metale, Memoria Antiquitatis 29-30, 431-482.

\section{DYMOWSKI 2017}

Dymowski, A., A Small Hoard of Roman Denarii Found in the Region of Kuyavia. The Provenance of Imitative Coins of Roman Imperial Denarii Found in the Territory of Poland, Notae Numismaticae - Zapiski Numizmatyczne 12, 111-124. DYMOWSKI 2018

Dymowski, A., Two barbarian imitations of Roman Imperial denarii found in Central Poland, Denarius: numizmatický časopis 7, 31-34.

DYMOWSKI/MYZGIN 2014

Dymowski, A./Myzgin, K., Inflow and redistribution of Roman imperial denarii in the area of Przeworsk, Wielbark and Chernyakhiv cultures and in the Baltic Islands in the light of chronological structure of coin hoards, Notae Numismaticae - Zapiski Numizmatyczne 9, 39-69.

DYMOWSKI et alii 2019

Dymowski, A./Bliujienè, A./Helle Horsnæs, H./Nielsen, R. H./Hunter, F./Lind, L./Militký, J./Munteanu, L./ Myzgin, K./Pelsdonk, J./Sidarovich, V./ Stoklas, B./Vida, I./Vojvoda, V./WiggWolf, D./Woytek, B., List of Roman Imperial Denarius Hoards from the European Barbaricum (under press).

\section{GATTORNO 1940}

Gattorno, L., Dinari subaerați de la Traian găsiți în Arrubium (Măcin), Cronica Numismatică și Arheologică 15/117-118, 232-236.

\section{GĂZDAC 2009}

Găzdac, C., The distribution of silver counterfeited coins in the forts of Roman Dacia: fraud or monetary policy?. In: Morillo, A./Hanel, N./Martín, E. (eds.), Limes XX. XX Congreso internacional de estudios sobre la frontera Romana/ XXth International Congress of Roman Frontier Studies, León (España), Septiembre 2006, III (Madrid: Polifemo), 1487-1498.

\section{GĂZDAC 2010}

Găzdac, C., Monetary Circulation in Dacia and the Provinces from the Lower Danube from Trajan to Constantine I (AD 106-337) ${ }^{2}$ (Cluj-Napoca: Mega Publishing House).

GĂZDAC/OARGĂ/ALFÖLDY-GĂZDAC 2015

Găzdac, C./Oargă, O./Alföldy-Găzdac, Á., It was supposed to be Silver! The Scrap Coin 'Hoard> Apulum VI (ClujNapoca: Mega Publishing House). 
HORSNÆS 2013

Horsnæs, H. W. Crossing boundaries. An analysis of Roman coins in Danish context. 2. Finds from Bornholm (Copenhagen: The National Museum of Denmark).

\section{HONCU/GAFINCU 2018}

Honcu, Șt./Gafincu, L., Descoperiri arheologice efectuate în situl de la Ruginoasa, județul Neamț, Arheologia Moldovei 41, 219-228.

HONCU/MUNTEANU 2018

Honcu, Șt./Munteanu, L., The Roman fibula in the hoard of Oboroceni (Heleșteni commune, Iași County). In: Aparaschivei, D./Bilavschi, G. (edd.), Studia romana et mediævalia europænsia. Miscellanea in honorem annos LXXXV peragentis. Professoris emeriti Dan Gh. Teodor oblata (București - Brăila: Academia Română Istros), 155-167.

IGNAT 1986-1987

Ignat, M., Contribuţii la cunoaşterea ceramicii dacice de la răsărit de Carpaţi. Vasele cu tezaure monetare din sec. II-III e.n., Suceava. Anuarul Muzeului Județean 13-14, 103-118.

IONIȚĂ/URSACHI 1988

Ioniță, I./Ursachi, V., Văleni - o mare necropolă a dacilor liberi (Iași: Junimea).

LIND 2007

Lind, L., A group of barbarous Roman denarii represented in Sweden and Hungary (and Germany and Britain?). In: Andersen, M./Horsnæs, H. W./ Moesgaard, J. C. (eds.), Magister Monetae. Studies in Honour of Jørgen Steen Jensen (Copenhagen: National Museum), 53-58.

LIND 2018

Lind, L., Roman Denarii. Hoards and Stray Finds in Sweden. 2018.1. Imitations of Roman Denarii found in Sweden (Stockholm: Numismatic Institute).

LUCCHELLI 1998

Lucchelli, T. M., La moneta nei rapporti tra Roma e l'Europa barbarica: aspetti e problemi (Firenze: La Nuova Italia).

MAGOMEDOV 2001

Magomedov, B. V., Černjachovskaja kul'tura: problema ètnosa (Lublin: Wyd. Uniwersytetu Marii Curie-Skłodowskiej). MARINESCU-BÎLCU/CHIȚESCU/

MIHAILESCU-BÎRLIBA 1989

Marinescu-Bîlcu, S./Chițescu, M./ Mihailescu-Bîrliba, V., Tezaurul de monede romane descoperit la Tîrpești, Studii și Cercetări de Numismatică 9, 43-51.

MIHAILESCU-BÎRLIBA 1980

Mihailescu-Bîrliba, V., La monnaie romaine chez les Daces orientaux (Bucarest: Academia R.S.R).

MIHAILESCU-BÎRLIBA 1981

Mihailescu-Bîrliba, V., Un problème de statistique mathèmatique: la réforme de Septime Sévère et les trésors monétaires romains au-dèlà des frontierès de l'Empire. In: Carcassonne, C./Hackens, T. (éds.), Statistique et numismatique. Table ronde organisée par le Centre de Mathématique Sociale de l'École des Hautes Études en Sciences Sociales de Paris et le Séminaire de Numismatique Marcel Hoc de l'Université Catholique de Louvain. Paris, 17-19 sept. 1979 (Strasbourg: Council of Europe), 324333.

MIHAILESCU-BÎRLIBA 1983-1985

Mihailescu-Bîrliba, V., "Le trésor unique" de l'Empire Romain, Memoria Antiquitatis 15-17, 117-125.

MIHAILESCU-BÎRLIBA 1991

Mihailescu-Bîrliba, V., Tezaurul de denari imperiali romani de la Gherăieștii Noi, jud. Neamț, Arheologia Moldovei 14, 57-65.

MIHAILESCU-BÎRLIBA 1994

Mihailescu-Bîrliba, V., Römische Münzen östlich der Provinz Dazien im 2.-3. Jh. u. Z., Arheologia Moldovei 17, 69-73.

MIHAILESCU-BÎRLIBA 1998

Mihailescu-Bîrliba, V., Keramik und Münzen. Die Behälter der Münzschätze 
aus den Gebieten der Freien Daker. In: Peter, U. (Hrsg.), Stephanos nomismatikos, Edith Schönert-Geiß zum 65. Geburtstag (Berlin: De Gruyter), 467-483.

MIHAILESCU-BÎRLIBA 2012

Mihailescu-Bîrliba, V., Roman coins at the free tribes outside Province of Dacia. In: Paunov, E./Filipova, S. (eds.), HPAK $\Lambda E O Y \Sigma \Sigma \Omega T H P O \Sigma \quad \Theta A \Sigma I \Omega N$. Studia in honorem Iliae Prokopov sexagenario ab amicis et discipulis dedicata (Veliko Turnovo: Faber), 507512.

MIHAILESCU-BÎRLIBA/MITREA 1975 Mihailescu-Bîrliba, V./Mitrea, I., Tezaurul de denari romani imperiali descoperit la Hertioana de Jos (com. Traian, jud. Bacău), Carpica 7, 15-29.

MIHAILESCU-BÎRLIBA/MITREA 1977

Mihailescu-Bîrliba, V./Mitrea, I., Tezaurul de la Măgura (Bacău: Muzeul de Istorie).

MIHAILESCU-BÎRLIBA/MITREA 1978

Mihailescu-Bîrliba, V./Mitrea, I., Le trésor de vases romains de Muncelul de Sus, Dacia. Revue d'archéologie et d'histoire ancienne 22, 201-212.

MITREA/MIHAILESCU-BÎRLIBA 2000-2001

Mitrea, B./Mihailescu-Bîrliba, V., Tezaurul de monede romane de la Bălănești (jud. Neamț), Arheologia Moldovei 2324, 199-208.

MITREA/MIHAILESCU-BÎRLIBA 2001

Mitrea, B./Mihailescu-Bîrliba, V., Un tezaur roman monetar puțin cunoscut, Văleni, jud. Neamț. In: Nicolae, E. (red. resp.), Simpozion de numismatică dedicat împlinirii a patru secole de la prima unire a românilor sub Mihai Voievod Viteazul, Chișinău, 28-30 mai 2000 (București: Enciclopedică), 63-72.

MITREA/ZAHARIA 1967

Mitrea, B./Zaharia, N., Descoperirea monetară de la Oboroceni (r. Pașcani, reg. Iași) și importanța sa istorică, Arheologia Moldovei 5, 81-121.

MOISIL 2010

Moisil, D., Un lot nou din tezaurul de de- nari romani imperiali decoperit la Muncelul de Sus, com. Mogoșești-Siret, jud. Iași, Cercetări Numismatice 16, 43-48.

MOISIL 2012

Moisil, D., Descoperiri monetare antice și bizantine din România (IV), Cercetări Numismatice 18, 293-322.

MUNTEANU 2017a

Munteanu, L., Some considerations of the Roman coin finds in the hinterland of the provinces of Dacia and Moesia Inferior. In: Caccamo Caltabiano, M. (ed.) - Carroccio, B./Castrizio, D./Puglisi, M./ Salamone, G. (coeds.), XV International Numismatic Congress Taormina 2015. Proceedings, I (Roma - Messina: Arbor Sapientiae), 925-929.

MUNTEANU 2017b

Munteanu, L., Moneda în așezările Daciei romane (Iași: Universitatea „Al. I. Cuza").

MUNTEANU/HONCU 2019

Munteanu, L./Honcu, Șt., Silver plated coins in the sites of Roman Dacia. In: Mihailescu-Bîrliba, L. (ed.), Limes, Economy and Society in the Lower Danubian Roman Provinces (Leuven: Peeters), 173-192.

MUNTEANU/MIHĂILESCU/DUMITROAIA 2017

Munteanu, L./Mihăilescu, D./Dumitroaia, Gh., Tezaurul de monede romane imperiale de la Dragomirești (jud. Neamț). In: Istina, L.-E. (ed.), In honorem magistri Ioan Mitrea octogenarii (Onești: Magic Print), 93-132.

MUNTEANU/MIHĂILESCU 2018

Munteanu, L./Mihăilescu, D., Tezaurul monetar roman de la Gârcina (jud. Neamț). In: Munteanu, L./Nicola, D./ Talmațchi, G. (ed.), Studia numismatica et archaeologica in honorem $\mathrm{V}$. Mihailescu-Bîrliba oblata (București - Piatra-Neamț: Academia Română Constantin Matasă), 213-258.

MUNTEANU/POPUȘOI 2014

Munteanu, L./Popușoi, E., The Roman Coin Hoard from Iezer, Anuarul 
Institutului de Istorie „A. D. Xenopol” 51, 1-34.

OANȚĂ-MARGHITU 2013

Oanță-Marghitu, R. (ed.), Aurul și argintul antic al României. Catalog de expoziție (București: Muzeul Național de Istorie a României).

OPREANU C. H. 1994

Opreanu, C. H., Neamurile barbare de la frontierele Daciei romane și relațiile lor politico-diplomatice cu Imperiul, Ephemeris Napocensis 4, 193-220.

PETAC 2011

Petac, E., Aspecte ale circulației monetare în Dacia romană (105 - 275 p.Chr.) (Wetteren: Moneta 115).

PETOLESCU 1988

Petolescu, C.C., Din nou despre pretinsul război al lui Caracalla contra carpilor, Studii și Cercetări de Istorie Veche și Arheologie 39/3, 281-286.

PETOLESCU 2010

Petolescu, C. C., Dacia: un mileniu de istorie (București: Academia Română).

POPA 2015

Popa, A., Untersuchungen zu den römisch-barbarischen Kontakten östlich der römischen Provinz Dacia (Bonn: Rudolf Habelt).

POPA 2016

Popa, A., Despre culturi arheologice şi identități etnice de la granițele provinciei romane Dacia. Studiu de caz: cultura Lipiţa versus costobocii, Acta Musei Tutovensis 12/2, 133-146.

RUSTOIU 1996

Rustoiu, A., Podoabe dacice de argint cu miez din metal de calitate inferioară, Ephemeris Napocensis 6, 43-54.

SANIE 1981

Sanie, S., Civilizația romană la est de Carpați și romanitatea pe teritoriul Moldovei. Secolele II î.e.n.-III e.n. (Iași: Junimea).

SANIE/SANIE/COJOCARU 1980

Sanie, S../Sanie, S./Cojocaru, M., Tezaurul de la Muncelul de Sus și unele probleme ale circulației monetare romane în Moldova, Cercetări Istorice 11, 249-268.

SANIE/ȘADURCHI 1976

Sanie, Ș./Șadurschi, P., Tezaurul de la

Dersca (jud. Botoșani), Cercetări Istorice 7, 83-90.

SERGEEV 2012

Sergeev, A., Barbarian coins on the territory between the Balkans and Central Asia: catalog of Andrei Sergeev's Collection at the State Historical Museum (Moscow) (Moscow: State Historical Museum).

\section{SIDAROVICH 2017}

Sidarovich, V., Barbarian Imitations of Ancient Coins in the Territory of Belarus, Notae Numismaticae - Zapiski Numizmatyczne 12, 125-141.

SPÂNU/DIMA/FRÂNCULEASA 2016

Spânu, D./Dima, M./Frânculeasa, A., The Mălăieştii de Jos (Prahova county) silver craftsman's hoard from the end of the third century AD, Dacia. Revue d'archéologie et d'histoire ancienne 60, 237-273.

STRIBRNY 2003

Stribrny, K., Funktionsanalyse barbarisierter, barbarischer Denare mittels numismatischer und metallur-gischer Methoden. Zur Erforschung der sarmatische-germanischen Kontakte im 3. Jahrhundert n. Chr. (Mainz am Rhein: Philipp von Zabern).

TUDOR 1976

Tudor, D., În legătură cu războiul lui Filip Arabul împotriva carpilor, Pontica 9, 89-96.

URSACHI 1995

Ursachi, V., Zargidava: Cetatea dacicã de la Brad (București: Caro Trading).

VOß/WIGG-WOLF 2017

Voß, H.-U./Wigg-Wolf, D., Romans and Roman finds in the Central European Barbaricum: a new view on RomanoGermanic relations?. In: González Sánchez, S./Guglielmi, A. (eds.), Romans and Barbarians beyond the Frontiers: Archaeology, Ideology and Identities in 
the North (Oxford : Oxbow Books), 105124.

ABBREVIATIONS:

AÉ

L’Année épigraphique, Paris.

CIL

Corpus Inscriptionum Latinarum, Berlin, I, 1863 sqq. 